\title{
Limitations of Induction Trainings Offered to Magistrates by State Judicial Educators in India
}

\author{
By Geeta Oberoi ${ }^{*}$
}

\begin{abstract}
This article raises concern on inferior training experience offered to magistrates by state judicial educators in India by providing details on ad hoc training arrangements that are diluting effectiveness of trainings offered. It compares continental France and common law country like India to point out the fact that public service exams to select magistrates offer hardly any competition as law graduates are easily selected as magistrates in India. It talks about importance of formation or induction training provided to prepare magistrate for their role and functions in France to suggest various good educational practices to be adopted from the French model of judicial training to reform the training model in India. The power dynamics between trainee judge and judicial education institution in India is also explored in this article to point how those dynamics are responsible for poor training experience for magistrates. Article offers comparative analysis that builds on existing literature about judicial training processes.
\end{abstract}

Keywords: Judicial training; Formation training; Subordinate judiciary; State judicial educator; Training duration.

\section{Introduction}

Even though administratively and politically, India is organised into a federation of 29 states and 7 union territories, on the judicial side hierarchy and jurisdictions are not federally organised. Judiciary is set up as a unified court system with the line of authority firmly fixed, both by statute and by court rules, running from the highest to the lowest branch of the judiciary. At the highest level is Supreme Court for the whole country with jurisdiction to try every kind of litigation whether between the government of the centre and those of the states, or between the governments of different states, or between individual and government or between individuals. Below it are established 24 high courts exercising their territorial jurisdiction over 29 states and 7 union territories. Below 24 high courts and under their supervision, different kinds and levels of trial courts are established and collectively all these trial courts are known as subordinate judiciary. ${ }^{1}$

Subordinate judiciary is itself hierarchically organised. Entry to it begins at the level of magistrate who is known as judicial magistrate (first class) [JMFC] when deciding criminal matters and civil judge junior division [CJJD] when

\footnotetext{
*Professor, National Judicial Academy India. The views in the Article are personal to author. Email: geetaoberoi@nja.gov.in_and geetaoberoi@ymail.com.

${ }^{1}$ Its constituent members in India dislike the phrase subordinate judiciary though it is used by the constitution under article 235. Also, all over the world, phrase is in use like France and no one anywhere has raised any objection against it. See Dunbar (1969).
} 
deciding civil matters. Entry is through competitive examination. ${ }^{2}$ The qualification prescribed to undertake competitive exam is basic law graduation degree (LL.B) and therefore young law graduates in the age group of 22 to 24 years right after their college days are selected as magistrates.

As the standard of legal education discourse in India did not improve ${ }^{3}$, the dangers of giving judgeship to such law graduates who did not possess sophisticated skills required for judicial decision making, ${ }^{4}$ led to several reports suggesting for in-depth judicial training to be given post recruitment known as induction training. ${ }^{5}$ One such report was by the First National Judicial Pay Commission (FNJPC).

\section{Context of setting up of the FNJPC and its findings}

In the All India Judges' Association Case ${ }^{6}$, the Supreme Court asked the government to constitute a separate Commission to study and prescribe uniform pay scales for judges all over the country. Pursuant to this observation, the Government of India by Resolution dated 21st March 1996 constituted FNJPC to suggest ways to improve conditions of subordinate judiciary. The FNJPC in its Report submitted in November 1999 dealt extensively on the subject of judicial training. In chapter 8 of FNJPC Report, information on Rules operating in different states and union territories within India for providing judicial trainings to the entry-level judges is provided. ${ }^{7}$ From this information, it emerged that high courts and state governments were providing some kind of training to magistrates. But amongst high courts and the states, there was no agreed upon syllabus for training, or its content or duration. There was no uniformity in pedagogy tools to be adopted for trainings. Therefore, FNJPC circulated a questionnaire to large number of judges to know their satisfaction with the trainings provided to them. Judges in response to this questionnaire pointed out following inadequacies:

(a) Most States have no training scheme nor training institutions;

(b) No proper continuing education programme at State or national level;

\footnotetext{
${ }^{2}$ Primary method of recruiting judges in France is also through competitive examination. But as compared to Indian competitive examination, French exam is extremely competitive and tough to get in. Further in France, clearing competitive exam only gives candidate entry in the ENM - French National School for the Judiciary (Ecole Nationale de la Magistrature). After induction training of 31 months at ENM which is known as professional formation, candidate is again required to take an exit examination to evaluate their capacity and then as per the result they are posted. In China also national judicial examination is held every year since year 2002 and all those who wish to practice law are required to succeed in this examination and if they want to become judges then they have to also clear national civil service exam. However, Zhu observes that national judicial exam in china has not helped in the goal of putting the best people in the courtroom. Zhu (2016).

${ }^{3}$ Baxi (1976), Mehren (1965).

${ }^{4}$ Haines (1959).

${ }^{5}$ The Law Commission of India reports $\left(14^{\text {th }}, 114^{\text {th }}, 116^{\text {th }}\right.$ and $\left.117^{\text {th }}\right)$ recommended for intensive training to be provided to judicial officer post selection.

${ }^{6}$ AIR 1992 SC 165

${ }^{7}$ http://www.indiancorruptjudges.com/Plot4Plot/fromweb/www.kar.nic.in/fnjpc/recrj.htm
} 
(c) People are sent for training at the fag end of their career;

(d) For shortage of judges, training periods reduced or training avoided altogether;

(e) Available schemes are neither scientifically organised nor based on experience;

(f) All judicial officers are unlikely to benefit from uniform training; therefore it must be selective and need-based;

(g) Most schemes are totally inadequate to enhance judicial capabilities and skills;

(h) Most schemes have no written test or examination to assess the impact of training;

(i) There is no thrust on specialisation and trainings are not linked to specific needs of work assigned;

(j) Training is not participatory and no interactive learning procedures adopted;

(k) Organization does not give priority or weightage to participation in training;

(l) The curriculum is not scientifically evolved nor is it periodically revised;

(m) Because of resource constraints, funds are not allocated for judicial training;

(n) There is no training on change of jobs or on promotion;

(o) There is no proper infrastructure for judicial training;

(p) Training not taken seriously either by the trainers or by the trainees;

(q) There is total absence of competent trainers who are skilled for the job;

(r) Some of the programmes are too localised and not standardised to serve larger goals;

(s) Objects of specific training programmes are not clearly formulated or communicated;

(t) Rhetorical lectures and exaggerated sermons by dignitaries do not inspire learning;

(u) Properly supervised attachment with efficient judicial personnel can help but senior has neither time nor motivation;

(v) Lack of trained permanent core teaching faculty is a serious handicap;

(w) Poor performance at training has no effect on career;

(x) Training for appreciation of scientific evidence and innovative approaches in judging is non-existent or superficial;

(y) Independent, well-meaning initiatives by magistrates are looked down upon and not encouraged.

FNJPC report at para 13.6.17 observed that

all the state judicial training institutions uniformly keep Senior District Judges as faculty members. It is not clear whether they are sent to these institutions by the High Court because of their pronounced talents in teaching and training or because it was felt necessary to keep them away from the courts for different reasons involving tasks of administration of Justice. In any case very few of them stay long enough to put in their best to the cause of judicial training. The need for extra-inputs for proper judicial training is met by guest faculty who are liberally used by most institutions. 


\section{Recommendations of FNJPC for improving induction training:}

FNJPC in para 8.1 of chapter 8 recommended for one year induction training course by qualified trainers [para 8.34], for fixing 35 years as the maximum age for eligibility for selection as magistrates with relaxation by 3 years for candidates in whose favour affirmative action is allowed by the constitution of India [para 8.44], for doing away with the requirement of 3 years' experience of practice in the Bar as a condition for entering the judicial service [para 8.35], for providing three advance increments to judge selected with master degree in law to reward appropriately such candidates [para 8.48], etc.

Further, in chapter 13, FNJPC observed that the primary reason for judicial delays, repeated appeals and legal uncertainties can be traced to the lack of required competence in terms of updated knowledge and skills on the part of judicial officers at several levels of the system. ... [T] here is no substitute to organised and appropriate training on a continuing basis which requires priority attention in the judicial reform agenda [para 13.1.10]. It also criticised the prevailing practice of training through attachment with courts of senior judges observing that the same has an inbuilt disadvantage of sustaining all past practices in disregard to needs of contemporary times [para 13.6.4].

As judges on existing programmes gave large numbers of adverse comments, FNJPC recommended radical changes to the existing training schemes if the resources spent have to give returns. [para 13.7.4] These recommendations were:

1. Judges in many States do not have any opportunity for organised institutional training; they learn day-to-day tasks through attachment with senior and experienced judges for 3 to 6 months after initial recruitment; this is found to be too inadequate for independent and efficient functioning. [para 13.7.4 Q3]

2. Regional language should not be the medium of instruction as it will affect judicial standards throughout country and will be unfair to the concept of equal justice under law. Legal literature of good quality is available at present only in English. Judicial excellence in present circumstances requires use of English language in judicial work. [para 13.7.4 Q11]

3. On an average, state judicial training institution may have a Principal and a Vice-Principal, two Professors, one or two Lecturers and two or three Research Officers. In any case, a minimum of five full-time faculty members should invariably be available to every training institution. [para 4 within para 13.7.4]

4. Though individuals are responsible in building institutions, it is the structure, character and traditions of institutions which can sustain and improve standards of performance long after promoters have disappeared from the scene. The goals set, the traditions built, the work culture developed, the extent of academic freedom provided and the type of core team of trainers initially assembled will largely determine the potential of the Academy to deliver and deliver it well. As such, great deal of attention has to be bestowed in selecting the Faculty and giving necessary autonomy 
to the Academy. It cannot be kept as an appendage of the High Courts almost entirely dominated by judges who may not have time or interest to supervise working of the Academy. Teaching is different from judging and the two should not be mixed up. [para 13.10.1]

5. State judicial training institution must have a core faculty of at least 5 professors with salaries and perquisites equivalent to that of High Court Judge, 6 Associate Professors with salaries and perquisites equivalent to that of a District Judge and few Lecturers/Tutors with status equivalent to that of Civil Judge. The visiting faculty is to be invited as required. Half the faculty (all ranks) may be recruited from the judiciary and the other half from legal academics, legal practitioners and social scientists with pronounced interest in the legal system and having pedagogic abilities. [para 13.10.2(b)]

6. A new work culture which is exacting, business-like, and performanceoriented if not generated in training institution, it will end up like mediocre, self-serving white elephants of the kind we have plenty in this country. The practice of sending people out from parent departments to training institutions when they are unproductive or otherwise not desired in service is to be totally abandoned if training is to become serious exercise directed towards efficiency and excellence. [para 13.10.2(e)]

\section{Transformations post-FNJPC Report vis-à-vis Induction Trainings}

As FNJPC submitted its report way back in the year 1999, and in the year 2017, the government of India on the directions of the Supreme Court set up a third national judicial pay commission to revise salary structure of subordinate judiciary, ${ }^{8}$ it becomes relevant to trace the changes effected to area of induction trainings in the last two decades.

One visible change in two decades is construction of judicial academies by almost all high courts in the country. We have now 24 state judicial academies (SJAs) corresponding to 24 high courts in the country. The second visible change is that SJAs are actively organizing trainings. The third visible change is that SJAs have their own annual academic calendar, which they need to submit to the Council established by the Supreme Court - the National Judicial Academic Council. $^{9}$ The fourth change was that the NJA adopted structural changes suggested by the FNJPC and SJAs regularly participate in faculty development initiatives annually organised at the NJA. Therefore, there are some visible positive changes forcing seriousness on the part of state judicial education provider, which was missing.

\footnotetext{
${ }^{8}$ http://www.newindianexpress.com/thesundaystandard/2017/oct/08/21000-lower-court-judgesto-get-pay-hike-1668395.html

${ }^{9}$ The NJAC was constituted by the CJI in CJ_CM conference of 29 April 2016. Since then this Council meets every year to finalise the annual calendars of the NJA as well as all the SJAs. It has met twice - one in July 2016 and another in June 2017. Therefore SJAs are now compelled to devise their annual academic training calendars.
} 
However, there are some concerns regarding (i) overlapping role of national judicial education provider (NJA) and SJAs; (ii) dwindling duration of induction trainings at the SJAs and (iii) overlooking structural recommendations of FNJPC by SJAs. These are discussed in detail here below:

\section{Overlapping Role of National and State Level Education Provider}

At present, SJAs are directed to submit their training calendars to the NJA. ${ }^{10}$ Pursuant to such direction from the Supreme Court of India, monthly reports and annual academic training calendar is submitted by SJAs. These reports indicate that state judicial educators (SJAs) are organizing one to two days' duration workshops, refresher courses, seminars and conferences for judges in their jurisdiction. Some of them organise regional conferences for judges from neighbouring jurisdictions. Undeniably, same educational experiences when offered at the national level by national educator, serve more useful function in terms of interchange of experiences, information and ideas. At the SJA level, it is not possible to generate required amount of information to satisfy the needs of the state judiciary or immediate needs of newly appointed magistrates. The courses at the SJAs fail to create any long term impact on trainees. Even if the same experts are engaged to deliver trainings at both NJA and SJAs, even then because of the freedom to voice out different experiences at the NJA and freedom to openly criticise existing state of affairs in open debates differentiate training experience gained at the NJA level. At the SJAs, there is one-way monologue style information dissemination from speaker to listener.

\section{Dwindling duration of Induction Trainings}

Some of the SJAs have started organizing regional meetings on few selected topics on their own. Some SJAs are even hosting foreign judges from Sri Lanka, Nepal, Bhutan and Bangladesh by arranging trainings for them. As more and more SJAs are getting preoccupied with the NJA model of trainings for judicial officers, their time, energy and resources are diverted to the NJA model of courses and thus reduced for induction courses. From the monthly progress reports submitted to the NJA by the SJAs and from the training calendar submitted for whole year activities, it emerges that for the academic year (AY) 2017-18:

1) Andhra Pradesh SJA delivered induction course for magistrates selected in the year 2014 by dividing them in two groups for duration of 2 months for both the groups. First batch was called in the SJA from 10 April 2017 to 11 June 2017 and the second batch came from 17 July 2017 to 30

\footnotetext{
${ }^{10}$ Resolutions adopted in the Chief Justices' Conference pertaining to judicial academies, i.e., point no. 9 (Strengthening of Judicial Academies and Introducing Innovative Methods for Imparting Training to Judicial Officers regarding their court functioning and Judgment writing and training to lawyers and capacity building and identification of potential). Vide this resolution all the SJAs have been asked to submit a monthly status report on number of trainings organised, nature of trainees, trainers, training methodologies etc.
} 
September 2017. It also delivered induction course to magistrates selected in the year 2015 from 6 November 2017 to 5 January 2018, i.e., for about 2 months.

2) Karnataka SJA for the AY 2017-18 conducted 4 months induction training programme for magistrates selected in the year 2014 by dividing these magistrates into two groups. The first group was provided induction training from 6 March 2017 to 12 May 2017 and 5 June 2017 to 29 July 2017. The second group was called from August 2017 to December 2017. The SJA also provided 4 months induction training to magistrates selected in the year 2016 by dividing them into two groups. The first group was provided training from April 2017 to July 2017 and the second group was given training from August 2017 to December 2017. The SJA also delivered 4 months induction training to magistrates selected in the year 2017 from April 2017 to August 2017.

3) Madhya Pradesh SJA delivered induction training for magistrates selected in the year 2014 by dividing them into two groups. The first group was called twice. Once from 6 March 2017 to 1 April 2017 and second time from 19 June 2017 to 14 July 2017. Therefore, the group was provided less than one month of training each time. The second group was also called twice for its induction training. Once from 24 April 2017 to 19 May 2017 and second time from 28 August 2017 to 23 September 2017. The second group was also provides less than one month training each time. The SJA organised induction training for magistrates selected in the year 2015 from 2 January 2017 to 28 February 2017 and for magistrates selected in the year 2017 from 23 October 2017 to 17 November 2017.

4) Uttarakhand SJA provided induction training to magistrates selected in the year 2014 from 4 June 2017 to 8 September 2017 and to magistrates selected in the year 2015, from 1 August 2017 to 15 October 2017 and then from 15 December 2017 to 15 April 2017.

5) Uttar Pradesh IJTR in the AY 2017-18 organised induction training for magistrates selected in the year 2014 by dividing them into two groups. The first group was called twice. First from 2 February 2017 to 1 May 2017 and next time from 2 November 2017 to 1 February 2018. The second group was also called twice: first from 15 May 2017 to 14 August 2017 and then from 15 February 2018 to 14 May 2018.

6) West Bengal SJA provided induction training to magistrates selected in the year 2014 from 19 June 2017 to 14 July 2017 and then from 17 July 2017 to 11 August 2017. It also delivered another induction training for another set of magistrates from 7 March 2017 to 9 June 2017.

7) Maharashtra SJA organised induction training for newly selected magistrates from 8 May 2017 to 1 July 2017.

8) Rajasthan SJA organised induction training for 72 newly selected magistrates in four intervals. First schedule was from 9 April 2017 to 27 May 2017, the second from 4 September to 23 September 2017, third from 4 December to 19 December 2017 and the last schedule from 26 March 2018 to 8 April 2018. 
9) Delhi SJA training calendar did not mention any induction training for the AY 2017-18. They informed on telephone that it is practice not to mention any dates for induction and they have no new batch for training for the AY 2017-18.

10) Assam SJA for the AY 2017-18 did not provide dates or duration of training courses but is a mere list of events and target groups that are planned.

11) Jammu and Kashmir SJA training calendar did not specify if it is organizing any induction-training course for AY 2017-18. Further it only mentions tentative months and not dates for one-day courses.

12) Jharkhand SJA training calendar did not specify any induction-training course for the AY 2017-18. Only two-day refresher courses for newly appointed magistrates were planned.

13) Tripura SJA informed that in the AY 2016-17 it conducted one induction training in which for first 3 months about half a day trainee judges were sent to the court to observe and other half day returned to the SJA for institutional training. Then for another 6 months they were posted in courts to observe working of courts. Then for next 3 months they come to the SJA in which about half a day, they were sent to the court to observe and for other half day come back to the SJA for institutional training. For the AY 2017-18, no induction training was conducted.

14) Though Chattisgarh SJA submitted its scheme of induction training for the AY 2017-18 which is 4 months institutional training at SJA, 2 months field training at the place of posting, followed by 2 months at SJA, 2 months again field training and final 2 months winding up training at SJA. There is no timetable provided as to when and for which batch this kind of training would be conducted.

\section{Analysis of Training Calendars submitted by the SJAs}

Andhra Pradesh SJA is training 2014 selected magistrates in the AY 2017-18. Due to large number, they were divided into two groups. Both groups are provided less than 4 and 1/2 months residential trainings. Andhra Pradesh SJA also claimed that it is providing 2 months residential training to 2015 selected magistrates in the AY 2017-18. Uttar Pradesh SJA also trained 2014 selected magistrates in the AY 2017-18. Due to large number, they were also divided into two groups. Both groups are provided 6 months residential trainings at the SJA. Uttarakhand SJA too provided induction training to magistrates selected in the year 2014 in the AY 2017-18. However, this induction course lasted only for 2 and $1 / 2$ months. Another induction training to magistrates selected in the year 2015 in the AY 2017-18 was for total of 6 and $1 / 2$ months. West Bengal SJA also provided induction training to magistrates selected in the year 2014 in the AY 2017-18 whose duration was for less than 2 months. It also provided induction training to some other magistrates for 3 months duration whose year of selection was not disclosed. Further, for the AY 2017-18, SJAs of Bihar, Delhi, Gujarat, Guwahati, Himachal Pradesh, Jammu 
and Kashmir, Jharkhand, Kerala, Meghalaya, Manipur, Orissa, Sikkim, Tripura and Tamil Nadu did not provide any induction course as reflected in their training calendars. They organised usual one day courses.

Though all SJAs claim to provide one-year induction course to newly recruited magistrates, their actual working and practices do not substantiate this claim. In practice, SJAs are far away from the goal of providing one year institutional training. The duration of induction courses for the AY 2017-18 reveals that not even one of them organised induction courses for continuous period of one year. The induction training is divided into many parts and it takes almost 2 to 3 years for a magistrate to complete his/her one-year induction course at the SJA. Many SJAs were in the AY 2017-18 preoccupied in offering induction training to magistrates selected in the year 2014.

SJAs are required to spend their time, effort and resources devoted exclusively for preparing robust and well-trained first level trial court judges in the career judiciary who are often recruited straight from their law college. With average mere 3 months foundation course in the SJAs, in the name of training, till confirmation to judgeship, rest of the time of trial court judge is spent in court attachments with senior judges. During this period, though trainee judges work, they do not get credits for the work done in this period.

\section{On-compliance with Structural Changes suggested by the FNJPC}

Even though we have now 24 SJAs functioning in 24 different parts of the country and these 24 SJAs are well financed by the government and given infrastructure capital by the state governments, impact wise these gigantic structures around the country will not be able to achieve anything intellectually or otherwise. As pointed out by the FNJPC report submitted way back in the year 1999, SJAs need to cut their umbilical cord from their parent high court as this uncut chord is turning the SJA just into an extension of the court itself. Of course, the SJAs being staffed with subordinate judiciary, are in no position to cut this umbilical cord. This chord has to be cut by the parent high court if the SJAs are to grow into a vibrant educational institution where mind is free from fear, new intellectual rays rush in and education takes primacy. The mind set of present high court justices proves that high courts are not yet ready to cut this umbilical cord.

High courts not only completely control state judicial education providers (SJAs) within their jurisdiction but are also desirous to control legal education discourse in their jurisdiction. There are high courts, which have established state judicial academy and national law school branch together at one campus so as to get it controlled by their judicial officer. ${ }^{11}$ Also, most high courts are to some extent controlling the national law schools established in their territorial jurisdiction.

Definitely, complete control of judges over the SJAs is contrary to what was recommended by the FNJPC. There is not even one SJA throughout India, which experimented with structure outlined by the FNJPC report. One wonders that why such recommendation on structural reshuffle remains totally ignored even till

\footnotetext{
${ }^{11}$ Delhi, Jharkhand and Assam are prime examples of this. But Delhi - SJA and NLS for reasons best known to functionaries, could not come together and work together.
} 
today? Why even for an experiment sake, this recommendation was not tested is not clear and one can only infer either ignorance of FNJPC recommendations or deliberate inaction.

SJAs continue to operate under same conditions as was even before the recommendations of the FNJPC - with the help of judicial officers. In some of the SJAs, these judicial officers take classes for judges and call upon retired judges of their high courts to take classes for induction batch. At some point, they also engage local academic staff and local experts for some subjects if approved by their high courts. Teaching method is mostly lecture, power point presentation by the speaker and question-answer sessions between trainer and those being trained. The problem lies in the fact that most of district judges and high court judges in India have educated under poor model of legal education and therefore there is a danger of repeating their own inferior educational experience at the SJA. Their ignorance on educational theories around training of adult professionals makes them reluctant to accept teaching innovations and new experiments for learning. Till this date, none of the SJAs ventured to develop new methods for the delivery of induction course curriculum. ${ }^{12}$

\section{Suggestions to Improve Induction Trainings provided Post Recruitment}

Importance of induction training for magistrates cannot be appreciated without realizing their role in the justice system. As noted by Haines ${ }^{13}$, magistrates set standards for administration of justice in their communities, they conduct trial for majority of criminal cases, they do fantastic volumes of work etc. For large number of cases or trials, no appeal is filed and their decision is final. Their courts are of first instance and last resort. Also to be noted that they are one of the oldest surviving constitutional institution in legal history. Their history began from 1195 when they were commissioned in England to keep the peace. ${ }^{14}$ Through England this institution travelled to its colonies.

However, as pointed out by Haines ${ }^{15}$, magistrates are quite alone in the discharge of their official duties and therefore they punish same crime differently and decide the same civil claim differently in their capacity as civil judges. Induction training provides them adequate time and opportunity to connect with their colleagues both at personal level as well as professional level thus reducing their isolation.

Secondly, except for trial court judges presiding over juvenile justice boards, for other regular magistrates, there is no system of doing follow up with persons who have been sentenced. As pointed out by Haines ${ }^{16}$, if a person must go to jail,

\footnotetext{
${ }^{12}$ Even basic - case exercise method, where trainee judges could be provided real life situations and asked to respond with observations by different stakeholders and who then could comment on their perspective to trainee judge - is not attempted at the SJAs. For case exercise method see Webb (1967).

${ }^{13}$ Haines (1959).

${ }^{14}$ Darbyshire (2002).

${ }^{15}$ Haines (1959).

${ }^{16}$ Haines (1959).
} 
all that magistrates can do is to open the door and push that person into an institution that magistrates have neither seen nor know much about. On what happens to the prisoner inside the jail, treatment and reformation of prisoner, or how effective was the sentence imposed - are not within the jurisdiction of magistrates. Magistrate is not counterpart of modern medicine practitioner who follows up the efficacy of his /her treatment. Induction training offers opportunities to trainee magistrate to travel to places that he/she will not get in their daily routine to study impact of decisions rendered by courts. Knowledge and experience gained during induction period on impact of incarceration will stay with magistrate even after training is completed and same will help in careful scrutiny of materials and evidences produced so that fundamental freedoms are not unnecessarily taken away by judicial decisions.

Thirdly, jurists and philosophers from different parts of the world have been equating justice with personality of the judge. ${ }^{17}$ Judge is considered, as a key factor in the administration of justice. ${ }^{18}$ There are numerous examples of great jurists who have opined that the quality of justice would be determined by the quality of the judges giving justice. ${ }^{19}$ Induction training has to prepare magistrates for change in treatment that will occur all around them once they assume judgeship and changes in all relations post their appointment to the bench. This change, as pointed out by Haines ${ }^{20}$, can spoil the personality of judge, and therefore, training has to raise consciousness of magistrate to this phenomena at their induction point.

Fourthly, even a fresh law graduate in India can get selected as a magistrate. The competitive exams, for selecting trial judges are not at all comparable to the concourse of ENM in France. ${ }^{21}$ Indian pattern of competitive exam is two hours preliminary exam of multiple-choice questions followed by three hour written exam to test knowledge of criminal law and procedure and three hour written exam to test knowledge of civil law and procedure followed by one-hour interview. Therefore, in total 9 hours examination, a law graduate can become a trial judge in India. Not enough has been researched into exam papers prepared for entry into state judicial service exams in India. However, old papers that are available in public domain and published in books for preparation of competitive judicial service exams point out that these examinations do not require much analytical skills from the test takers. Although a lot of short mock cases are included in the exam, these tests, as pointed by Zhu with respect to China's National Judicial Exam ${ }^{22}$, do not intend to put the test taker into real life situation, but merely list objective elements and see if the test taker can match it with the

\footnotetext{
${ }^{17}$ John Dugard refers to authoritative studies in the United States, Canada, Britain, Australia and Israel which show convincingly that unreasonable and unjust disparity in sentencing is largely attributable to differences in judicial personality. Dugard (1985).

${ }^{18}$ Address of Roscoe Pound to American Bar Association in 1906 at St. Paul Minnesota titled "the causes of popular dissatisfaction with the administration of justice."

${ }^{19}$ Clark (1969).

${ }^{20}$ Haines (1959).

${ }^{21}$ Ecole Nationale de Magistrature is training institution set up since 1958 to provide solid training to magistrates in France.

${ }^{22}$ Zhu (2016).
} 
corresponding rule. In France, on the other hand, students after receiving their master degree in law faculty - if they are interested in advocacy, they have to take the exam to enter the CRFPA $^{23}$ which is regional professional formation centre for advocates and if they want to become judges or prosecutors, they have to take the ENM concourse. French believe that magistrates and advocates should develop different mind-set from the very beginning of their career. The ENM is in charge of forming the young law students into competent judges during 31 months training. However, it is not easy to enter ENM. There is no score line that the participants have to get in exams. There is 7 hour dissertation and case analysis on criminal law and procedure, 7 hour dissertation and case analysis on civil law and procedure, 5 hour dissertation on comprehension of modern society, 2 hours short answer to questions on organization of the state, 5 hours synthesis memorandum, 30 minutes oral exam on English language and 30 minutes oral exam on optional language, 25 minutes oral presentation on random topic on EU law and 25 minutes oral presentation on random topic on social and commercial law, 40 minutes group role play in front of judges/jury, 40 minutes oral presentation and debate with the judges/jury. ${ }^{24}$

As compared to 9 hours devoted to select trial judges in India, in France, after obtaining master's degree one has to go through 29 hour rigorous competitive exam to get selected in the training school for judges, and it is left to the training school after final exit exam to declare trainee fit to take up role of judge or prosecutor. Such a huge difference in selection process of trial judges definitely has impact on quality of judges selected. It therefore becomes necessary to see that at induction training sufficient experience, knowledge and the attitude is provided to magistrates to get them over their mediocrity. For, as noted by Clark, mediocrity can pollute as badly as criminality. Mediocrity is more pervasive - it is present in every case tried by a mediocre judge. Corruption picks and chooses cases, awaiting the most vulnerable one. The victims of mediocrity are those who cannot appeal because of their penury. ${ }^{25}$

Fifthly, accepting the report of FNJPC, the Supreme Court in All India Judges' Association and Ors. v. Union of India and Ors. ${ }^{26}$ directed high courts and state governments to amend their Rules to enable the fresh law graduate to be eligible to compete and enter the judicial service. Elimination of 3 years practice as qualification requirement to undertake competitive examination to become magistrate is another reason for intense induction trainings. As noted by Davis ${ }^{27}$, even judges with long experience of legal practice need training to help them cope with complexity of judicial work because judicial skills and legal skills are not synonymous. Intense induction training is needed to provide expertise in psychology, sociology, social work, finance and accounts management, communication and ethics so that these young magistrates in both criminal and

\footnotetext{
${ }^{23}$ Centre Régional de formation professionnelle des avocats

${ }^{24}$ Zhu (2016).

${ }^{25}$ Clark (1969).

${ }^{26}(2002) 4$ SCC 247.

${ }^{27}$ Davis (2005)
} 
civil work are able to explore the opinions, values and prejudices which might influence their work.

Sixthly, as noted by Zhu for Chinese National Judicial Exam, competitive exams held to select judges have failed to put the best jurists into courtroom. ${ }^{28}$ Magistrates whether in South Africa during apartheid period or in Nazi Germany or in India with respect to riot related trials ${ }^{29}$ have proved to be instruments in the hands of oppressive state and failed to distinguish positive model of law from larger and universal principles of justice. Studies by Gready and Kgalema ${ }^{30}$ point out that magistrates perceive themselves as state employees and fail to exercise discretion, which they have to check abuses of state power. Training of magistrates based on positivism, ad hoc reliance on peer guidance and self education inextricably bound up with nationalization led to politicization of magistrates in South Africa and they became bound to apartheid state and articulators of its world view. Similarly Markovits ${ }^{31}$ found that East German judges perceived themselves as public servants who are supposed to apply and implement the law rather than interpret and analyse it. Their training took away discretion available to check excessive state power violating human rights. Failure of magistrates in South Africa or Nazi Germany to check human rights violation of substantial population of their country provides a good reason for re-thinking on peer training model adopted by most countries for their judicial education discourse. Engagement of persons outside professional ranks of Bar and Bench as suggested by the FNJPC report is therefore necessary to provide objective training at induction level.

Seventhly, Dickson's comparison of magistracy in England and in America ${ }^{32}$ informs us that whereas lay magistrates of England and Wales decide straightforward cases in straightforward manner, and as collegial courts and their decisions reflect a collective common sense; in America, where lay magistracy has vanished, there is much law and less justice in the hands of legally trained magistrates. This observation compels reflection on the content of induction training discourse as to how it is to be selected to train magistrates to decide cases in simple manner without compromising ideals of justice and fairness.

Eighthly, though magistrates during induction courses visit forensic labs, observation homes for juveniles, courtrooms and such attendance in itself is a rewarding experience, seldom they are guided and mentored during these visits. Most often it is regarded as a break from classroom lectures and treated as a picnic and outing. Though senior judge from the training institution (SJA) often accompany them, they themselves treat the visit as a break from their official routine. In contrast, the ENM in France send their trainee magistrates to insurance companies (to study how claims are processed), to national railways (to study how accidents take place), to airports (to study aerial security), to customs and excise department (to study problem of identification), apart from departments of

\footnotetext{
${ }^{28} \mathrm{Zhu}(2016)$.

${ }^{29}$ As noted by Harsh Mander, trial courts in India have failed to hold political actors accountable for damage done during riots. Mander (2015).

${ }^{30}$ Gready \& Kgalema (2003).

${ }^{31}$ Markovits (1995).

${ }^{32}$ Dickson (1992).
} 
manpower, social security, labour etc. They are also made to attend consultations at psychiatric hospitals, medico-legal institutes etc. ${ }^{33}$ In Switzerland, to ensure a better understanding of prison conditions, judicial officers are required to spend a short period in prison disguised as prisoners. ${ }^{34}$ Further, France, Japan, Tunisia, Thailand, Greece, Poland, Spain etc. send their trainee magistrates to foreign training institutions to prevent the inculcation of an attitude to life which is too scholastic, uniform and ex cathedra. ${ }^{35}$ SJAs therefore need to arrange visits beyond their jurisdiction during induction trainings to provide meaningful experience to young judges. If quality of justice is to improve, some 20 to 30 percent of magistrates undertaking induction training who perform well during the training discourse should be seconded with foreign state judicial education institutions as is done in France. ${ }^{36}$ Such exposure will help magistrates to wipe out caste, religion, region and gender biases and broaden their outlook about the society.

Ninthly, SJAs need to be made autonomous bodies so that they can create linkages with universities for sharing of resources and methods. In 1980, the University of Virginia in the United States established a graduate programme for judges leading to the award of the degree of Master of Laws (LL.M) in the judicial process. For the same, judge had to satisfactorily complete two successive summer sessions of six weeks each and write a thesis under faculty supervision. This course was created specifically on demand of judges. ${ }^{37}$ SJAs need to partner with local universities and national law schools in their states to design and develop exclusive courses for judges. We know that National Law School at the state of Andhra Pradesh known as NALSAR had developed diploma courses for training of the court managers. But Andhra Pradesh SJA did not give very encouraging support to this initiative of the law school and further, the high court of Andhra Pradesh discontinued the services of court managers and winded up the idea of engagement of court managers. Such instances do not motivate law schools to support SJAs in their training affairs.

Tenthly, SJAs in partnership with the local universities can provide an indepth content for its courses. The professional curriculum developers and legal academia from universities can be suitably engaged by giving perks and emoluments suitable to their stature for updating and modifying induction course contents every year. Regular engagement of law professors at the SJA can solve this problem to a great extent. Faculty engaged by the SJA can undertake research on the case law generated from the state judiciary to point out areas of concern to be addressed via judicial trainings. The use of these well-trained professionals could eliminate ad-hocism from induction training and guarantee training in line with the professional practices followed in learning institutions. SJAs therefore need to employ first of all regular academicians and send them to EMN France to learn good practices from French model of training and use these practices back home to improve induction trainings.

\footnotetext{
${ }^{33}$ Dunbar (1969).

${ }^{34}$ Dugard (1985).

${ }^{35}$ Dunbar (1969).

${ }^{36}$ Dunbar (1969).

${ }^{37}$ Kennedy (1987).
} 
Eleventh, during 31 months induction training in ENM in France, faculty of 25 in ENM develop training actions for sessions in which nearly 2000 judges and professionals from all sectors, both private and public, intervene in the sessions. ${ }^{38}$ A magistrate during 31 months at ENM France ${ }^{39}$ is offered a modern and profound training in the great variety of problems, which they will regularly encounter in the exercise of their functions. The curriculum embraces not only private law but also public, financial and social law. It is not confined to judicial process but trainee has to complete training in economic, social, administrative and technical fields. The training does not confine itself to law and procedure but aims at increasing human experience of induction batch judges. ${ }^{40}$ SJAs can add extra-judicial functions as part of induction trainings. Induction judges can be sent to work as paralegal volunteers with rural legal aid centre. Such exposure to legal aid work during their induction itself will minimise the reservations expressed at latter part of their career, about their involvement with the legal aid work. Another area of dislike by trial judges is pertaining to their role in encouraging ADR. Reluctance to accept their role in ADR can also be reduced by making them resolve real disputes through mediation, arbitration, conciliation etc. during their induction training.

Twelfth, like ENM in France, SJAs must in induction training create a space for internships and send trainee judges to academic institutions to expose them to utility of research in different areas and learn professional techniques and functional specificities of the judgeship. As in China, where to become a judge one has to clerk before the senior judges, SJAs could deisgn internships to make young judges take one months clerkship under high court and Supreme Court justices. Further, trainee judges could also be attached for period of one month with the office of prosecution, with law firms, with important chambers, with NGOs, with police stations, with jails, with shelter homes, etc. Such diverse attachment and internship experiences would provide them sensitivity and seriousness required for decision making profession.

Thirteenth, SJAs must be monitored and evaluated annually. It should be mandatory for them to prepare their annual report on the lines prepared by the NJA and submitted to the Parliament. The report of the SJA must be tabled in the state legislature and discussed. The full time Director of the SJA must be held accountable for budget, expenditure, structure, resources, methodology opted for induction trainings and impact of trainings.

Lastly, as noted by Dunbar ${ }^{41}$, the task of future trial judges is necessarily more exacting, for it is increasingly difficult to maintain public order and social stability in a rapidly changing world and to preserve human values in the midst of technical and scientific progress which threatens to outstrip mankind. Therefore SJAs must plan for induction training, which not only provides judicial techniques but also a clear and vibrant perspective of current developments in the fields of culture,

\footnotetext{
${ }^{38} \mathrm{http}: / / \mathrm{www} . \mathrm{enm}$.justice.fr

${ }^{39}$ The name was changed from National Centre for Judicial Studies to Ecole Nationale de Magistrature in 1970 and training period increased from 28 months to 31 months.

${ }^{40}$ Dunbar (1969).

${ }^{41}$ Dunbar (1969).
} 
economics and sociology. Peer training model need not be abandoned but there could be some structural adjustments made around that model.

\section{References}

Baxi, U. (1976). 'Notes Towards A Socially Relevant Legal Education: A Working Paper for the UGC Regional Workshop in Law' in Journal of the Bar Council of India 5(13):1-33.

Clark, Justice T.C. (1969). 'Improving the Administration of Justice' in McGill Law Journal 15(1):1-8.

Darbyshire, P. (2002). Magistrates in (ed. M. McConville and G. Wilson) The Handbook of the Criminal Justice Process (OUP: 285-309).

Davis, M. (2005). 'A new training initiative for the lay magistracy in England and Wales a further step towards professionalization?' in International Journal of the Legal Profession 12(1):93-119.

Dickson, D. (1992). 'The Selection and Appointment of Magistrates in England and Wales' in, University of Toledo Law Review 23:697-733.

Dugard, J. (1985). 'Training Needs in Sentencing in South Africa' in South African Journal of Human Rights 1:93-105.

Dunbar, N.C.H. (1969). 'The French Magistracy' in University of Tasmania Law Review 3:159-173.

Gready, P. \& L. Kgalema (2003). 'Magistrates under Apartheid: A case study of the politicization of Justice and Complicity in Human Rights Abuse' in South Africa Journal of Human Rights $19: 141-188$.

Haines, E.L. (1959). 'The Case for the Training of Magistrates', Criminal Law Quarterly 2:207-213.

Kennedy, G.A. (1987), 'Training for Judges?' in University of New South Wales Law Journal 10:47-59.

Mander, H.. (2015). Looking Away, Speaking Tiger publication, New Delhi.

Markovits, I. (1995). Imperfect Justice: An East-West German Diary. Clarendon Press.

Mehren, A.T. von (1965). 'Law and Legal Education in India: Some Observations' in Harvard Law Review 78:1180-1189.

Webb, A.M.F. (1967), 'The Training of Justices of the Peace in England and Wales' in Canadian Journal of Corrections 9(2):105-114.

Zhu, M. (2016). 'Towards a Professionalized Judiciary: An Insight into the Ongoing Chinese Reform on Judicial Selection in Comparison with France' in Indonesian Journal of International and Comparative Law 3:147-182.

\section{Cases}

All India Judges' Association v. Union of India, 1992 AIR 165.

All India Judges' Association and Ors. v. Union of India and Ors (2002) 4 SCC 247.

\section{Online Reports}

http://www.indiancorruptjudges.com/Plot4Plot/fromweb/www.kar.nic.in/fnjpc/recrj.htm http://www.newindianexpress.com/thesundaystandard/2017/oct/08/21000-lower-courtjudges-to-get-pay-hike-1668395.html

http://www.enm.justice.fr

The Law Commission of India reports $\left(14^{\text {th }}, 114^{\text {th }}, 116^{\text {th }}\right.$ and $\left.117^{\text {th }}\right)$. 